\title{
Boundary relationships between pre-Caledonian and Caledonian lithostructural units in the East Greenland Caledonides $72^{\circ}-74^{\circ} \mathrm{N}$
}

\author{
A. K. Higgins and J. D. Friderichsen
}

In 1978 a further season of geological reconnaissance work was carried out in the inner fjord region of East Greenland between latitudes $72^{\circ}-74^{\circ} \mathrm{N}$. This work set out to establish a modern updated framework for the classic geological studies carried out by Lauge Koch's expedition (Haller, 1971; Koch \& Haller, 1971) and was an extension of the Survey's work in the Scoresby Sund region between 1968 and 1972. New field work by the writers and others, supported by radiometric age determinations, has already contributed much new data (Rex et al., 1976, 1977; Higgins et al., 1978; Thyrsted, 1978). In 1978 several important localities were revisited, and 1:20000 mapping undertaken in key areas south of Nunatakgletscher, in Knækdalen, around Kap Hedlund and in Forsblads Fjord (fig. 29).

The ages attributed to the different lithostructural units in this account refer to the period when each developed its essential petrological and structural character, as deduced from isotopic studies and geological reasoning. It is emphasised that all the pre-Caledonian units have suffered regional metamorphism, deformation and perhaps partial remobilisation during the Caledonian orogeny, and that Caledonian granite intrusions invade the older rock units in many areas.

\section{Boundary between Caledonian sediments and middle Proterozoic lithostructural units}

Middle Proterozoic migmatites and granites have been recognised in two separate areas: a wedge-shaped area south of Kap Hedlund and another wedge-shaped area north of Kejser Franz Josephs Fjord (fig. 29). Their western boundary is an east dipping thrust, while the eastern boundary with the Eleonore Bay Group sediments is usally a tectonic feature corresponding to the 'zone of detachment' or 'abscherungszone' of the classic 'stockwerke' model (Haller, 1971).

In the north, on the south side of Nunatakgletscher, the east dipping contact is slightly discordant to the bedding in the Eleonore Bay Group. Biotite and hornblende gneisses, augen gneisses, amphibolites and sillimanite-kyanite schists occur below the contact, a lithological association of 'basement' aspect from which an unpublished middle Proterozoic $\mathrm{Rb}$-Sr isochron age (c. 1000 m.y.) has been obtained for a granitic body in Eremitdal (D. C. Rex, personal communication). The Eleonore Bay Group sediments above the contact are slightly metamorphic, containing garnet and staurolite in appropriate lithologies, and are deformed by major $\mathrm{N}-\mathrm{S}$ trending structures of box fold type. The contact is interpreted as a décollement zone, in the field seen as a series of closely related shear zones involving wedges of basement and Eleonore Bay Group lithologies.

In the south the contact has been examined on both sides of Forsblads Fjord. Below the contact occur high grade sillimanite bearing migmatites and migmatite granites, identical to 

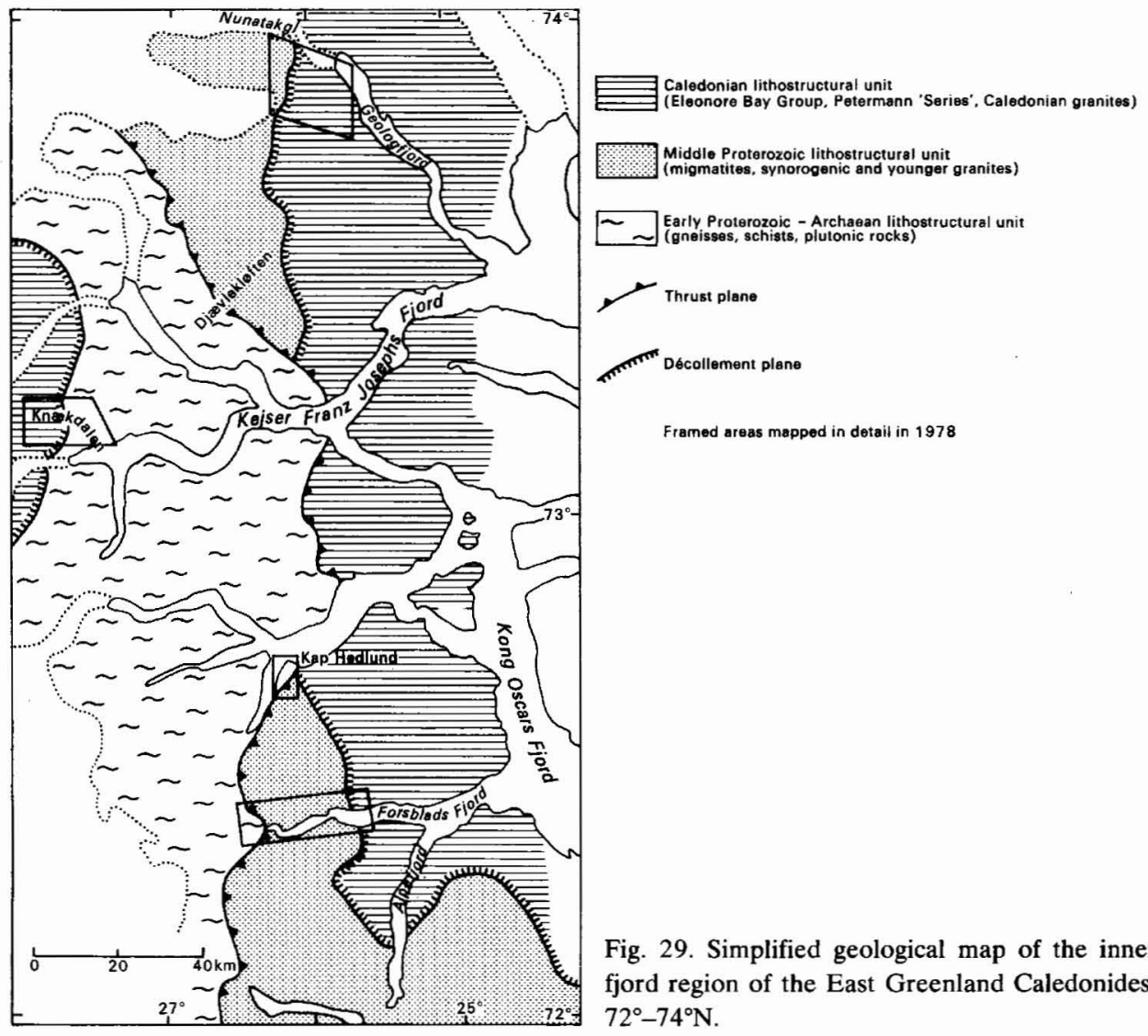

Fig. 29. Simplified geological map of the inner fjord region of the East Greenland Caledonides, $72^{\circ}-74^{\circ} \mathrm{N}$.

units in the Scoresby Sund region from which middle Proterozoic zircon and $\mathrm{Rb}$-Sr isochron ages have been obtained (Steiger et al., in prep.). Above the contact thick sequences of Lower Eleonore Bay Group quartzites and schists are invaded by major and minor Caledonian granites. The Eleonore Bay Group schists contain, near to the contact, staurolite, garnet and locally nodular developments of fibrolitic sillimanite suggesting high temperature, low pressure Caledonian metamorphism (T. Thyrsted, personal communication). On the south side of the fjord, the contact is marked by several movement zones with mylonitic developments, whereas on the north side of the fjord the contact is not so markedly tectonised, though there are possible planes of shear which may involve slices of migmatitic rocks. Younger Caledonian granite sheets cut the rock units on both sides of the contact.

\section{Boundary between Caledonian sediments and early Proterozoic - Archaean litho- structural units}

Early Proterozoic - Archaean infracrustal rocks are widely exposed in the inner fjord zone (fig. 29) and in many areas are overlain by early to middle Proterozoic metasediments. 
Caledonian sediments, represented by the lateral equivalent of the Eleonore Bay Group known as the Petermann 'Series', overlie the older rock units in the west, and were investigated in Knækdalen (Odell, 1939; Wenk \& Haller, 1953; Higgins et al., 1978). The contact here is a movement zone, but dips to the west, cutting slightly discordantly across the Petermann 'Series' so that at least $2000 \mathrm{~m}$ of the sequence known farther west is cut out. Structures in the Petermann 'Series' trend N-S, and, as in parts of the Eleonore Bay Group outcrop, are developed as large scale box folds. A thick sequence of partly migmatitic metasediments occurs beneath the contact, and at the bend of Knækdalen this rests on granitic gneisses dated at 1725 m.y. (Higgins et al., 1978). The contact is interpreted as a décollement zone, with appreciable but unknown amount of movement, typically involving tectonic slices of the older and younger units.

\section{Boundary between early Proterozoic-Archaean and middle Proterozoic lithostruc- tural units}

Throughout the region an east dipping thrust or system of faults and thrusts, separates these, very differently developed units. Infracrustal rocks west of the thrust have yielded $\mathrm{Rb}-\mathrm{Sr}$ isochron ages in the range $1800-2000 \mathrm{~m} . \mathrm{y}$., while between latitudes $70^{\circ}-72^{\circ} 30^{\prime} \mathrm{N}$, mainly Archaean ages have been recorded. The dominant rock types east of the thrust are migmatites and migmatite granites, with in some areas non-migmatitic, medium grade sedimentary sequences; isotopic ages between 950-1250 m.y. suggest a middle Proterozoic time of development (Rex et al., 1977; Steiger et al., in prep.).

The thrust system is traceable continuously from latitude $73^{\circ} 30^{\prime} \mathrm{N}$ to $70^{\circ} \mathrm{N}$. Everywhere the contact has been examined thick zones of mylonites, ultramylonites, crushed and retrogressed gneisses have been found. At Kap Hedlund the thrust cuts obliquely across the middle Proterozoic migmatites into the Lower Eleonore Bay Group, causing severe shearing in the sediments and in Caledonian granite sheets.

The thrust system is a late Caledonian tectonic feature of possibly considerable displacement as it has brought units of different character and age into contact with one another.

\section{References}

Haller, J. 1971: Geology of the East Greenland Caledonides, 413 pp. New York: Interscience Publishers.

Higgins, A. K., Friderichsen, J. D., Rex, D. C. \& Gledhill, A. R. 1978: Early Proterozoic isotopic ages in the East Greenland Caledonian fold belt. Contr. Miner. Petrol. 67, 87-94.

Koch, L. \& Haller, J. 1971: Geological map of East Greenland $72^{\circ}-76^{\circ} \mathrm{N}$. Lat. (1:250 000). Meddr Grønland 183, 26 pp.

Odell, N. E. 1939: The structure of the Kejser Franz Josephs Fjord region, North-East Greenland. Meddr Grønland 119, 6, 53 pp.

Rex, D. C., Gledhill, A. R. \& Higgins, A. K. 1976: Progress report on geochronological investigations in the crystalline complexes of the East Greenland Caledonian fold belt between $72^{\circ}$ and $74^{\circ} \mathrm{N}$. Rapp. Grønlands Geol. Unders. 80, 127-133.

Rex, D. C., Gledhill, A. R. \& Higgins, A. K. 1977: Precambrian Rb-Sr isochron ages from the crystalline complexes of the inner Forsblads Fjord, East Greenland fold belt. Rapp. Grønlands Geol. Unders. 85, 122-126. 
Steiger, R. H., Hansen, B. T., Schuler, Ch., Bär, M. T. \& Henriksen, N. in prep.: Isotopic age determinations revealing the polyorogenic nature of the southern Caledonian fold belt in East Greenland. Submitted to J. Geol.

Thyrsted, T. 1978: Structural and metamorphic studies in the East Greenland Caledonides between $72^{\circ}$ and $74^{\circ}$ N. Rapp. Grønlands Geol. Unders. 90, 94-99.

Wenk, E. \& Haller J. 1953: Geological explorations in the Petermann region, western part of Frænkels Land, East Greenland. Meddr Grønland 111, 3, 48 pp.

\section{Observations on the Upper Permian of Wegener Halvø, East Greenland}

\section{Lars Stemmerik}

The Upper Permian sediments of East Greenland are exposed from Scoresby Land in the south to Clavering $\varnothing$ in the north (fig. 30). The deposits on Wegener Halvø appear to be situated on the eastern side of the southern end of an elongated, approximately $80 \mathrm{~km}$ wide, sedimentary basin (Birkelund \& Perch-Nielsen, 1976). Whether this basin extended northwards to include the Upper Permian deposits of North Greenland, has yet to be established.

The Upper Permian sequence, which is predominantly marine limestones, shales and associated sandy units, rests unconformably on Devonian and Permo-Carboniferous rocks. All the sediments of Upper Permian age are referred to the Foldvik Creek Formation (Koch, 1929). This earlier work was revised, based on sections around Clavering $\emptyset$, and later the formation was divided into eight members (Maync, 1942, 1961). Recently, most of the units have been traced southwards into the Scoresby Land area (Perch-Nielsen et al., 1972). A regression in late Permian - early Triassic time affected the basin of deposition. Continuous sedimentation across the boundary is only known in the area of Schuchert Elv (Perch-Nielsen et al., 1972).

The present investigations are concerned with basin development and faunal distributions through this sequence (fig. 31). Fieldwork in summer 1978 aimed at establishing both faunal and sedimentological reference profiles. All work is supported by the Danish Natural Science Research Council (SNF).

\section{Observations and preliminary results}

In the southern part of Wegener Halvø sedimentation commenced with a 5-10 m (locally more than $30 \mathrm{~m}$ ) thick conglomerate, of probably marine origin. This Conglomerate Member of Myanc (1961) is overlain by a $20-40 \mathrm{~m}$ thick brecciated dolomite, which to the north marks the base of the Upper Permian. The breccia is mainly composed of blocks, of questionable Permian limestone, floating in a dolomitic matrix. General clast size of the breccia diminishes from $20 \mathrm{~cm}$ in the east of the basin to $3 \mathrm{~cm}$ in the west. In the south blocks exceed $10 \mathrm{~m}$ indicating a proximal source area.

The succeeding limestone thickness varies towards the central part of the basin, from 